\title{
PENDAPATAN ASLI DAERAH,TRANSFER DAERAH, DAN BELANJA MODAL, PENGARUHNYA TERHADAP PERTUMBUHAN EKONOMI REGIONAL DI INDONESIA
}

\author{
Agus Sunarya Sulaeman \\ Politeknik Keuangan Negara STAN \\ asunarya@pknstan.ac.id \\ Vivin Silvia \\ Politeknik Keuangan Negara STAN \\ vivinsundaprima@gmail.com
}

\begin{abstract}
Abstrak:
Penelitian ini bertujuan untuk menguji dan membuktikan secara empiris mengenai pengaruh Pendapatan Asli Daerah (PAD), Transfer Daerah, dan Belanja Modal terhadap pertumbuhan ekonomi daerah. Transfer Daerah terdiri dari Dana Alokasi Umum (DAU), Dana Bagi Hasil (DBH) dan Dana Alokasi Khusus (DAK). Populasi ini adalah pemerintah daerah kabupaten dan kota di Indonesia dari website Direktorat Jenderal Perimbangan Keuangan dan Badan Pusat Statistik. Pengujian dilakukan menggunakan metode kuantitaif dengan analisis data panel. Hasil analisis menunjukkan bahwa PAD berpengaruh signifikan dan positif terhadap pertumbuhan ekonomi. DAU berpengaruh signifikan dan positif terhadap pertumbuhan ekonomi, DBH berpengaruh signifikan dan positif terhadap pertumbuhan ekonomi, DAK tidak berpengaruh signifikan terhadap pertumbuhan ekonomi. Begitupun dengan belanja modal berpengaruh signifikan dan positif terhadap pertumbuhan ekonomi.
\end{abstract}

Kata Kunci: Pendapatan Asli Daerah, Transfer Daerah, Belanja Modal, Pertumbuhan Ekonomi.

\section{PENDAHULUAN}

Pertumbuhan ekonomi merupakan salah satu indikator utama dalam mengukur tingkat ekonomi suatu negara yang berkaitan erat dengan pembangunan nasional. Todaro dan Smith dalam Nugraha (2014) menyatakan bahwa keberhasilan pembangunan nasional yang dilaksanakan pemerintah dapat diukur salah satunya dengan melihat pertumbuhan ekonomi yang telah berhasil dicapai. Pertumbuhan ekonomi Indonesia dalam 5 tahun terakhir (2013 s.d.2017) belum mencapai target yang ditetapkan dalam APBN. Selain itu, apabila dilihat dalam lingkup regional terdapat variasi pertumbuhan ekonomi, seperti Provinsi Bali dan Nusa Tenggara mengalami penurunan pertumbuhan ekonomi yang cukup signifikan pada tahun 2016 dan 2017, namun di Provinsi Jawa dan Sumatera 
mengalami kenaikan pertumbuhan ekonomi. Pertumbuhan ekonomi yang bervariasi tersebut menunjukkan adanya ketidakmerataan pertumbuhan ekonomi di seluruh Indonesia. Seperti dilansir oleh metrotvnews.com pada 11 Mei 2018, Menteri PPN/Kepala Badan Perencanaan Pembangunan Nasional, Bambang Brodjonegoro, menyatakan bahwa sekitar 80\% kontribusi wilayah terhadap pertumbuhan ekonomi nasional berasal dari kawasan Barat Indonesia, khususnya pulau Jawa dan Sumatera. Sementara itu, kawasan Timur Indonesia masih belum berkontribusi secara optimal terhadap pertumbuhan ekonomi nasional.

Pemerintah daerah memiliki peranan penting dalam menggerakkan perekonomian di daerahnya. Salah satu upaya yang dilakukan oleh pemerintah untuk mendorong pertumbuhan ekonomi daerah melalui kebijakan desentralisasi yang diterapkan oleh pemerintah. Desentralisasi fiskal merupakan salah satu komponen utama dari desentralisasi. Oates (1999:1120) menyatakan bahwa desentralisasi fiskal dapat menghasilkan alokasi sumber daya di sektor publik yang lebih efisien dan ekonomis karena pemerintah daerah lebih memahami kebutuhan daerahnya. Efisiensi tersebut akan memicu pertumbuhan ekonomi yang lebih cepat di daerah dan berdampak pada pertumbuhan ekonomi nasional.

Kebijakan desentralisasi fiskal sejalan dengan amanat Undang-Undang Republik Indonesia Nomor 33 tahun 2004 tentang Perimbangan Keuangan antara Pemerintah Pusat dan Pemerintah Daerah. Melalui desentralisasi fiskal, pemerintah daerah diberi kewenangan untuk mengatur pendapatan dan pengeluaran yang diperlukan dalam menyediakan pelayanan publik. Melalui desentralisasi fiskal, pemerintah daerah diberi kewenangan untuk mengatur pendapatan dan pengeluaran yang diperlukan dalam menyediakan pelayanan publik. Sidik (2002:2) menyatakan bahwa apabila pemerintah daerah melaksanakan fungsinya secara efektif, dan diberikan kebebasan dalam pengambilan keputusan penyediaan pelayanan di sektor publik, maka harus didukung sumber-sumber keuangan yang memadai baik yang berasal dari Pendapatan Asli Daerah (PAD) termasuk surcharge of taxes, bagi hasil pajak dan bukan pajak, pinjaman, maupun subsidi/bantuan dari pemerintah daerah.

Dalam pelaksanaan desentralisasi, pemerintah daerah mempunyai kewenangan untuk memperoleh pendapatan sendiri melalui penerimaan pajak dan retribusi sesuai peraturan perundang-undangan yang dikenal sebagai Pendapatan Asli Daerah (PAD). Namun, PAD tersebut belum cukup untuk mendanai seluruh kebutuhan daerah dalam rangka pelaksanaan desentralisasi. Oleh karena itu peran pemerintah diperlukan untuk membantu pemerintah daerah melalui transfer ke daerah. Transfer pemerintah ke daerah cenderung mengalami kenaikan dari tahun ke tahun. Pada awal implementasi desentralisasi fiskal tahun 2001, transfer ke daerah besarnya Rp81,05 Triliun atau 24\% dari total APBN, sedangkan tahun 2017 total transfer ke daerah sebesar Rp741,99 Triliun atau 36,96\% dari total 
APBN. Dari total dana transfer ke daerah, dana perimbangan yang terdiri Dana Alokasi Umum (DAU), Dana Bagi Hasil (DBH), dan Dana Alokasi Khusus (DAK) merupakan dana yang dikelola langsung oleh pemerintah daerah melalui Anggaran Pendapatan dan Belanja Daerah (APBD). Dana perimbangan digunakan oleh pemerintah daerah untuk memenuhi kebutuhan daerah melalui belanja pemerintah daerah.

Desentralisasi fiskal dari sisi pengeluaran mengharuskan pemerintah daerah untuk mengalokasikan belanja daerah yang dapat mendorong pertumbuhan ekonomi. Kebijakan Pemerintah terkait belanja negara dilakukan terutama untuk mengalihkan belanja yang konsumtif menjadi belanja produktif dalam rangka akselerasi pertumbuhan ekonomi serta percepatan realisasi belanja. Dalam Nota Keuangan RAPBN 2018, untuk mengakselerasi pertumbuhan ekonomi yang berkeadilan pemerintah melakukan penguatan kualitas belanja salah satunya dengan meningkatkan belanja modal. Belanja modal yang dilakukan oleh pemerintah daerah diharapkan dapat menggerakkan perekonomian di daerah sehingga berkontribusi terhadap pertumbuhan ekonomi secara nasional.

Fenomena pertumbuhan ekonomi yang tidak mencapai target yang ditetapkan APBN dan tidak meratanya pertumbuhan ekonomi dalam lingkup regional menandakan bahwa pelaksanaan desentralisasi fiskal di Indonesia belum sepenuhnya mampu mendorong pertumbuhan ekonomi. Oleh karena itu, penulis tertarik untuk melakukan penelitian yang berjudul "Pengaruh Pendapatan Asli Daerah, Dana Alokasi Umum, Dana Bagi Hasil, Dana Alokasi Khusus dan Belanja Modal terhadap Pertumbuhan Ekonomi Kabupaten/Kota di Indonesia". Penelitian ini dilakukan untuk tahun anggaran 2013 s.d. 2017.

\section{TELAAH LITERATUR DAN PENGEMBANGAN HIPOTESIS}

\section{Teori fiscal federalism}

Teori fiscal federalism memberikan kerangka normatif secara umum mengenai pembagian fungsi pada level pementahan yang berbeda dan instrumen fiskal yang sesuai untuk menjalankan fungsi tersebut (Oates, 1999). Teori ini secara umum membahas bahwa pertumbuhan ekonomi dapat dicapai melalui adanya desentralisasi fiskal atau pendelegasian wewenang dari pemerintah pusat kepada pemerintah daerah. Oates dalam Zhang dan Zhou (1998:94) menyatakan pendapat bahwa desentralisasi akan meningkatkan efisiensi ekonomi karena pemerintah daerah berada dalam posisi yang lebih baik dibandingkan pemerintah pusat untuk memberikan pelayanan publik yang sesuai dengan karakteristik dan kebutuhan daerahnya, sehingga efisiensi tersebut akan memicu pertumbuhan ekonomi yang lebih cepat di daerah dan nasional.

\section{Pertumbuhan ekonomi}

Menurut Sadono Sukirno (2011:423), pertumbuhan ekonomi berarti 
perkembangan fiskal produksi barang dan jasa yang berlaku di suatu negara, seperti pertambahan dan jumlah produksi barang industri, perkembangan infrastruktur, pertambahan jumlah sekolah, pertambahan produksi sektor jasa dan pertambahan produksi barang modal. Pertumbuhan ekonomi merupakan perubahan tingkat kegiatan ekonomi yang berlaku dari tahun ke tahun. Suatu perekonomian dikatakan mengalami pertumbuhan apabila tingkat kegiatan ekonomi lebih tinggi dari apa yang telah dicapai pada periode waktu sebelumnya. Mankiw (2014:13) mengungkapkan Produk Domestik Bruto (PDB) merupakan ukuran yang sering digunakan untuk mengukur kinerja ekonomi atau tingkat pertumbuhan ekonomi, dimana PDB meringkas efektivitas ekonomi dalam suatu nilai uang tertentu selama periode waktu tertentu. Perhitungan PDB terbagi menjadi dua yaitu, PDB atas dasar harga berlaku dan PDB atas dasar harga konstan. Dalam perhitungan pertumbuhan ekonomi digunakan PDB atas dasar harga konstan yang mengabaikan pengaruh inflasi. Dalam Konsep regional, Produk Domestik Bruto dikenal sebagai Produk Domestik Regional Bruto.

\section{Desentralisasi Fiskal}

Desentralisasi fiskal merupakan sebuah alat untuk mencapai salah satu tujuan bernegara, yaitu terutama memberikan pelayanan publik yang lebih baik dan menciptakan proses pengambilan keputusan publik yang lebih demokratis (Sidik, 2002:1). Undang-Undang Nomor 33 Tahun 2004 tentang Perimbangan Keuangan Antara Pusat dan Daerah menjelaskan pengertian desentralisasi adalah penyerahan wewenang pemerintahan oleh Pemerintah kepada daerah otonom untuk mengatur dan mengurus urusan pemerintahan dalam sistem Negara Kesatuan Republik Indonesia. Secara umum, konsep desentralissi terdiri dari desentralissi politik (political decentralization), desentralisasi administratif (administrative decentralization), desentralisasi ekonomi (economic or market decentralization).

Desentralisasi fiskal merupakan salah satu komponen utama dari desentralisasi. Menurut Akai dan Sakata (2002:95), desentralisasi fiskal diinterpretasikan sebagai pelimpahan wewenang terkait pengambilan keputusan pada level pemerintahan yang lebih rendah dengan menggunakan pendekatan akuntansi untuk mengukur tingkat kewenangan yang dialokasikan kepada pemerintah daerah, yaitu dari segi pendapatan dan pengeluaran. Melalui desentralisasi fiskal, pemerintah daerah diberi kewenangan untuk mengatur pendapatan dan pengeluaran yang diperlukan dalam menyediakan pelayanan publik. Melalui desentralisasi fiskal, pemerintah daerah diberi kewenangan untuk mengatur pendapatan dan pengeluaran yang diperlukan dalam menyediakan pelayanan publik. 


\section{Pendapatan Asli Daerah}

Salah satu wujud dari pelaksanaan desentralisasi fiskal adalah pemberian sumber-sumber penerimaan bagi daerah yang dapat digali dan digunakan sendiri sesuai dengan potensinya masing-masing (Sidik, 2002). Menurut Halim dalam Setiyawati (2007), Pendapatan Asli Daerah adalah penerimaan yang diperoleh daerah dari sumber-sumber dalam wilayahnya sendiri yang dipungut berdasarkan peraturan daerah sesuai dengan peraturan perundang-undangan. Berdasarkan Undang-Undang Nomor 33 Tahun 2004 tentang Perimbangan Keuangan Antara Pusat dan Daerah, Pendapatan Asli Daerah (PAD) adalah pendapatan yang diperoleh daerah yang dipungut berdasarkan peraturan daerah sesuai dengan peraturan perundang-undangan.

\section{Dana perimbangan}

Sebagai wujud desentralisasi fiskal yang merupakan transfer dana dari pemerintah pusat kepada pemerintah daerah yang terdiri dari DAU, $\mathrm{DBH}$, dan DAK. Dana Alokasi Umum (DAU) merupakan dana yang bersumber dari pendapatan APBN yang dialokasikan dengan tujuan pemerataan kemampuan keuangan antar daerah untuk mendanai kebutuhan daerah dalam rangka pelaksanaan desentralisasi. DAU merupakan general purpose grant (bantuan umum), yaitu dana yang diberikan oleh pemerintah pusat kepada pemerintah daerah tanpa adanya syarat penggunaan tertentu atas dana tersebut. DAU bersifat block grant dimana penggunaannya diserahkan kepada daerah sesuai dengan prioritas dan kebutuhan daerah untuk peningkatan pelayanan kepada masyarakat dalam rangka pelaksanaan otonomi daerah.

Dana Bagi Hasil (DBH) adalah dana yang bersumber dari pendapatan APBN yang dialokasikan kepada daerah berdasarkan angka persentase untuk mendanai kebutuhan daerah dalam rangka pelaksanaan desentralisasi. Tujuan DBH adalah untuk memperbaiki keseimbangan vertikal antara pusat dan daerah dengan memperhatikan potensi daerah penghasil. Sama halnya dengan DAU, DBH merupakan general purpose grant (bantuan umum) dimana penggunaannya tidak memiliki adanya syarat penggunaan tertentu atas dana tersebut.

Dana Alokasi Khusus selanjutnya disebut DAK adalah dana yang bersumber dari pendapatan APBN yang dialokasikan kepada daerah tertentu dengan tujuan untuk membantu mendanai kegiatan khusus yang merupakan urusan daerah dan sesuai dengan prioritas nasional. Dilihat dari karakteristiknya, DAK merupakan jenis transfer specific-purpose grant (bantuan khusus). Jenis dana transfer ini dapat mengharuskan penerima untuk menyediakan dana pendamping tertentu (matching) atau tanpa dana pendamping (non-matchingi). Transfer yang bersifat matching dapat berbentuk open-ended (pemberi transfer akan menyanggupi berapapun dana yang dibutuhkan sesuai dengan kemampuan penerima) atau closed- 
ended (pemberi transfer membatasi jumlah dana yang akan ditransfer sesuai dengan anggaran yang dimiliki). DAK termasuk dalam specific matching closed-ended grant.

\section{Belanja modal}

Berdasarkan Peraturan Menteri dalam Negeri (Permendagri) Nomor 13 Tahun 2006 sebagaimana telah diubah dengan Permendagri Nomor 59 Tahun 2007, belanja modal adalah pengeluaran yang dilakukan dalam rangka pembelian/pengadaan atau pembangunan aset tetap berwujud yang mempunyai nilai manfaat lebih dari 12 (dua belas) bulan untuk digunakan dalam kegiatan pemerintahan. Saragih (2014:221) menyatakan bahwa dalam struktur belanja langsung pemerintah provinsi, kebjakan belanja modal sangat penting dan strategis dalam mendorong pertumbuhan ekonomi daerah, termasuk juga dalam konteks struktur belanja dalam APBD kabupaten/kota. Lebih lanjut, Saragih (2014:221) menyatakan sulit untuk mengharapkan percepatan pertumbuhan ekonomi daerah apabila porsi anggaran belanja modal (belanja langsung) tidak meningkat secara signifikan. Hal ini dikarenakan kualitas belanja langsung sangat vital mendorong pertumbuhan ekonomi dan sebagai instrumen dalam peningkatan kesejahteraan masyarakat yang dilihat dan diukur dari semakin banyaknya pembangunan infrastruktur publik di daerah-daerah. Nurudeen dan Usman dalam Darma (2014: 25), dalam penelitiannya menyatakan bahwa meningkatkan belanja pemerintah ke dalam instrastruktur transportasi dan komunikasi dapat berpengaruh positf terhadap pertumbuhan ekonomi.

Sutama dan Ismawati (2018) melakukan penelitian menggunakan analisis dengan model regresi linear berganda. Hasil penelitian menunjukkan bahwa secara parsial PAD berpengaruh signifikan terhadap pertumbuhan ekonomi, sedangkan dana perimbangan kurang memiliki pengaruh yang signifikan terhadap pertumbuhan ekonomi. Penelitian lainya, Anwar, et al. (2018) menunjukkan bahwa PAD berpengaruh positif dan signifikan terhadap pertumbuhan ekonomi, dana otonomi khusus berpengaruh positif dan signifikan terhadap pertumbuhan ekonomi. Sedangkan belanja modal berpengaruh negatif terhadap pertumbuhan ekonomi. Penelitian yang dilakukan oleh Nopiani, et al. (2016) menggunakan analisis jalur dengan obyek penelitian adalah kabupaten Buleleng. Hasil penelitian menunjukkan bahwa PAD, DAU, dan belanja modal berpengaruh positif terhadap pertumbuhan ekonomi.

Dewi dan Suputra (2017) yang berjudul "Pengaruh Pendapatan Asli Daerah, Dana Alokasi Umum, Dana Alokasi Khusus dan Belanja Modal Terhadap Pertumbuhan Ekonomi" menggunakan metode analisis regresi linear berganda. Populasi dalam penelitian ini adalah delapan kabupaten dan satu kota provinsi di Bali periode 2011 s.d. 2014. Hasil penelitian menunjukkan bahwa pendapatan asli daerah dan dana alokasi khusus 
berpengaruh negatif dan signifikan terhadap pertumbuhan ekonomi. Sedangkan dana alokasi umum dan belanja modal tidak berpengaruh terhadap pertumbuhan ekonomi.

Penelitian yang dilakukan oleh Panggabean (2017) menunjukkan bahwa variabel PAD, DBH, dan DAU berpengaruh positif terhadap pertumbuhan ekonomi. Sementara itu, variabel DAK tidak berpengaruh terhadap pertumbuhan ekonomi di Provinsi Lampung.

\section{Hipotesis Penelitian}

Hipotesis yang akan diuji terkait pengaruh pendapatan daerah dan belanja modal terhadap pertumbuhan ekonomi regional, yaitu:

$H_{1}$ : PAD berpengaruh positif terhadap Pertumbuhan ekonomi regional.

$\mathrm{H}_{2}$ : DAU berpengaruh positif terhadap Pertumbuhan ekonomi regional.

$\mathrm{H}_{3}$ : $\quad$ DBH berpengaruh positif terhadap Pertumbuhan ekonomi regional. regional.

$\mathrm{H}_{4}$ : $\quad$ DAK berpengaruh positif terhadap Pertumbuhan ekonomi

$\mathrm{H}_{5}$ : Belanja Modal berpengaruh positif terhadap Pertumbuhan ekonomi regional.

\section{METODE PENELITIAN}

Tujuan dari penelitian ini adalah untuk menguji dan membuktikan secara empiris mengenai pengaruh Pendapatan Asli Daerah (PAD), Dana Alokasi Umum (DAU), Dana Bagi Hasil (DBH), Dana Alokasi Khusus (DAK), dan belanja modal terhadap pertumbuhan ekonomi daerah. Data yang digunakan adalah data PDRB atas dasar harga konstan untuk melihat pertumbuhan ekonomi dan realisasi PAD, DAU, DBH, DAK, dan belanja modal di kabupaten/kota dari tahun 2013 sampai dengan tahun 2017. Populasi penelitian ini adalah pemerintah daerah kabupaten dan kota di Indonesia sebanyak 514 kabupaten/kota, dan yang memenuhi kriteria sampel adalah 479 kabupaten/kota, sehingga jumlah pengamatan yang dianalisis menjadi 2395. Data tersebut bersumber dari website Direktorat Jenderal Perimbangan Keuangan dan Badan Pusat Statistik. Pengujian dilakukan menggunakan metode kuantitaif dengan analisis regresi data panel. 
Gambar C.1 Kerangka Penelitian

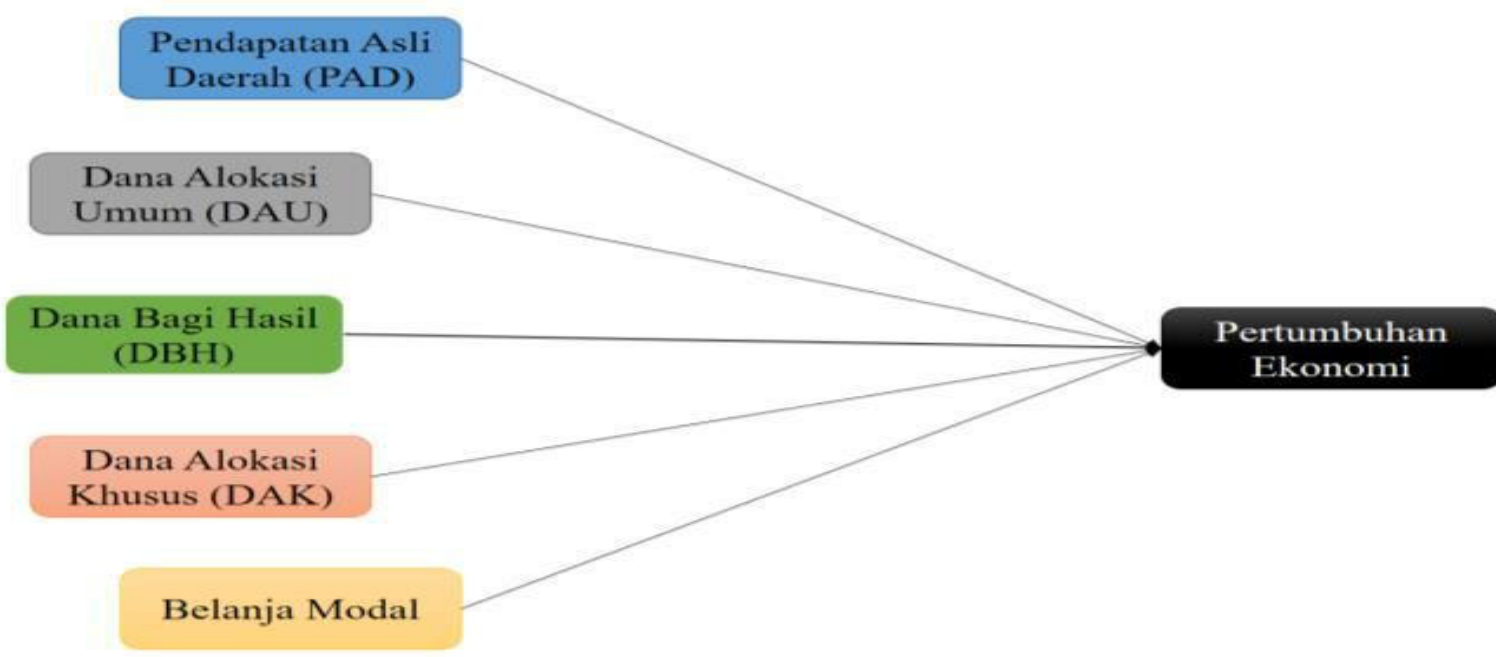

Sumber: Diolah oleh Penulis

Persamaan Model: $Y=a+\beta P A D+\beta D A U+\beta D B H+B D A K+\beta B M+$ Keterangan:

$\mathrm{Y} \quad=$ Pertumbuhan Ekonomi

PAD = Pendapatan Asli Daerah

DAU = Dana Alokasi Umum

DBH = Dana Bagi Hasil

DAK = Dana Alokasi Khusus

BM = Belanja Modal

$\mathrm{a} \quad=$ konstanta

$\beta_{1,2,3,4,5}=$ koefisien masing-masing variabel independen

$\mathrm{e}=$ error

\section{HASIL PENELITIAN DAN PEMBAHASAN}

\section{Analisis Model Regresi Terpilih}

Setelah dilakukan uji asumsi klasik dan memenuhi persyaratan pengujian, maka dilakukan regresi panel data. Hasil dari regresi model dan model regresi untuk pengaruh PAD, DAU, DBH, DAK, dan belanjamodal terhadap pertumbuhan ekonomi kabupaten/kota ditunjukkan pada Tabel 1.2 . 
Tabel 1.2. Hasil Model Regresi

\begin{tabular}{|c|c|c|c|}
\hline \multicolumn{4}{|c|}{$\begin{array}{l}\text { Dependent Variabel: ECPDRB } \\
\text { Method: Panel EGLS (Cross-section random effects) }\end{array}$} \\
\hline Variabel & Coefficient & t-Statistic & Probability \\
\hline C & $2.419,474$ & 2,327552 & 0,0201 \\
\hline PAD & 17,21352 & 4,133957 & 0,0000 \\
\hline DAU & 13,59633 & 5,463373 & 0,0000 \\
\hline DBH & 5,998299 & 2,173102 & 0,0299 \\
\hline DAK & $-0,909879$ & $\begin{array}{c}- \\
0,466642\end{array}$ & 0,6408 \\
\hline $\mathrm{BM}(-2)$ & 1,235781 & 1,737982 & 0,0824 \\
\hline$R$-squared & 0,450037 & F-statistic & 234,1988 \\
\hline $\begin{array}{l}\text { Adjusted } R- \\
\text { squared }\end{array}$ & 0,448116 & $\begin{array}{l}\text { Prob (F- } \\
\text { stat.) }\end{array}$ & 0,000000 \\
\hline
\end{tabular}

Persamaan Model:

$\mathrm{Y}=2.419,474_{(\mathrm{t})}+17,21352 \mathrm{PAD}_{(\mathrm{t})}+13,5963 \mathrm{DAU}_{(\mathrm{t})}+5,998299 \mathrm{DBH}$ $(\mathrm{t})-0,909879 \mathrm{DAK}_{(\mathrm{t})}+1,235781 \mathrm{BM}_{(\mathrm{t}-2)}+\mathrm{e}$

\section{Uji Koefisien Determinasi (Adjusted $\boldsymbol{R}^{2}$ )}

Nilai koefisien adjusted $\mathrm{R}^{2}$ dalam penelitian ini yang ditunjukkan dalam Tabel D.1.2. adalah 0,450037 atau sebesar 45\%. Nilai tersebut menunjukkan bahwa variabel independen dalam model dapat menjelaskan sebanyak $45 \%$ variasi variabel dependen. Sedangkan sebanyak $55 \%$ variasi variabel dependen dijelaskan oleh variabel independen lainnya yang tidak dijelaskan dalam model persamaan regresi dalam penelitian ini.

\section{Uji Signifikasi Simultan (Uji F)}

Hasil uji statistik F disajikan dalam Tabel 1.3. Berdasarkan Tabel 1.3., nilai probabilitas F-statistic adalah 0,0000 dimana nilai tersebut lebih kecil dari 0,05 yang artinya $\mathrm{H}_{a}$ diterima. Dengan kata lain, variabel-variabel independen pada persamaan tersebut memiliki pengaruh signifikan secara bersama-sama terhadap variabel dependennya. 
Tabel 1.3. Nilai Prob. One Tailed Variabel Independen

\begin{tabular}{|c|c|c|}
\hline Variabel & $\begin{array}{c}\text { Nilai Prob. untuk } \\
\text { One Tailed }\end{array}$ & Keterangan \\
\hline PAD & 0,0000 & Hipotesis diterima \\
\hline DAU & 0,0001 & Hipotesis diterima \\
\hline DBH & 0,0149 & Hipotesis diterima \\
\hline DAK & 0,3204 & Hipotesis ditolak \\
\hline BM(-2) & 0,0412 & Hipotesis diterima \\
\hline
\end{tabular}

Sumber: Diolah dari Nilai Prob. Pada Tabel D.1.2

\section{Hasil Uji Hipotesis}

\section{Pengaruh PAD terhadap Pertumbuhan ekonomi regional (H1)}

Hasil penelitian menunjukkan bahwa variable PAD secara parsial berpengaruh positif terhadap pertumbuhan ekonomi. Hasil penelitian ini sejalan dengan penelitian Hendriwiyanto (2014) yang menyatakan bahwa semakin tinggi PAD suatu daerah, maka tingkat ketergantungan fiskal daerah tersebut kepada pemerintah pusat semakin berkurang, sehingga daerah lebih leluasa dan fleksibel dalam merencanakan alokasi anggaran sesuai dengan agenda ekonominya. Setyawati (2007) dalam penelitiannya menyimpulkan bahwa PAD berpengaruh signifikan positif terhadap pertumbuhan ekonomi kabupaten/kota di Provinsi Jawa Timur tahun 2001 s.d. 2005. Setyawati mengungkapkan bahwa semakin tinggi PAD, maka semakin meningkat laju pertumbuhan ekonomi. Hal ini dikarenakan pajak dan retribusi daerah dikembalikan kepada masyarakat untuk mengembangkan dan menumbuhkan perekonomian daerah.

Pemerintah daerah yang memiliki PAD dengan jumlah yang besar lebih leluasa dan fleksibel dalam merencanakan alokasi anggaran belanja untuk kegiatan pembangunan sesuai dengan agenda ekonomi daerah. Salah satunya dengan belanja yang langsung terkait dengan percepatan pembangunan fasilitias pelayanan publik dan ekonomi sehingga mampu meningkatkan aktivitas ekonomi rakyat dan menunjang pertumbuhan ekonomi yang optimal. Peningkatan penerimaan PAD mampu meningkatkan kemandirian fiskal pemerintah daerah sehingga pemerintah daerah memiliki kemampuan untuk membiayai program-program sesuai dengan kebutuhan daerah yang mendukung pertumbuhan ekonomi.

\section{Pengaruh DAU terhadap Pertumbuhan Ekonomi Regional (H2)}

Hasil penelitian menunjukkan bahwa variabel DAU secara parsial berpengaruh positif terhadap pertumbuhan ekonomi. Hasil penelitian ini sejalan dengan penelitian Permanasari (2013) yang menyatakan bahwa DAU berpengaruh positif terhadap pertumbuhan ekonomi disebabkan peran DAU sangat signifikan karena belanja daerah leih didominasi oleh jumlah DAU. DAU berpengaruh terhadap pertumbuhan ekonomi dapat disebabkan karena nilai DAU yang diterima kabupaten/kota cukup besar, dilihat dari 
jumlah rata-rata DAU yang diterima kabupaten/kota merupakan jumlah pendapatan daerah terbesar, sehingga DAU berperan penting dalam membiayai kebutuhan daerah yang mendorong pertumbuhan ekonomi seperti belanja pegawai, belanja infrastruktur, dan belanja daerah lainnya.

Secara umum, sebagian besar pemerintah daerah memanfaatkan DAU untuk belanja pegawai. Bila dikaitkan dengan pertumbuhan ekonomi, pertumbuhan ekonomi dapat dipicu oleh konsumsi masyarakat yang merupakan pegawai pemerintah daerah, dimana penghasilannya berasal dari belanja pegawai yang dananya bersumber dari DAU. Selain untuk belanja pegawai, nilai DAU yang cukup besar dialokasikan oleh pemerintah daerah untuk program-program pemerintah daerah yang bertujuan meningkatkan pelayanan publik atau belanja infrastruktur yang dapat menjadi pemacu pertumbuhan ekonomi regional maupun ekonomi nasional.

\section{Pengaruh DBH terhadap Pertumbuhan Ekonomi Regional (H3)}

Hasil penelitian menunjukkan bahwa variabel DBH secara parsial berpengaruh positif terhadap pertumbuhan ekonomi. Hasil penelitian ini sejalan dengan peneltian yang dilakukan Hendriwiyanto (2014) yang menyatakan bahwa secara parsial DBH berpengaruh positif terhadap pertumbuhan ekonomi di Provinsi Jawa Timur tahun 2010 s.d. 2012 dan penelitian Panggabean (2017) bahwa DBH berpengaruh positif dan signifikan terhadap pertumbuhan ekonomi di kabupaten/kota di Provinsi Lampung tahun 2011 s.d. 2015.

Taaha et al dalam Hendriwiyanto (2014) menjelaskan bahwa alokasi DBH sebagai sumber pembiayaan infrastruktur berupa sarana dan prasarana ekonomi akan menunjang kegiatan produksi barang dan jasa oleh investor baik dari masyarakat setempat ataupun dari luar daerah yang bersangkutan. Kegiatan investasi yang dilakukan akan menciptakan kesempatan kerja dan memberikan multiplier effect sehingga berpengaruh terhadap pertumbuhan ekonomi. Pemanfaatan DBH diserahkan sepenuhnya kepada pemerintah daerah, sehingga pemerintah daerah memiliki fleksibilitas memanfaatkan DBH untuk mendanai program-program sesuai kebutuhan daerah dan menunjang pertumbuhan ekonomi seperti belanja infrastruktur dan pelayanan publik.

\section{Pengaruh DAK terhadap Pertumbuhan Ekonomi Regional (H4)}

Hasil penelitian menunjukkan bahwa variabel DAK tidak berpengaruh signifikan terhadap pertumbuhan ekonomi. Hasil penelitian ini sejalan dengan penelitian yang dilakukan oleh Setyawati (2007) dan bahwa DAK tidak berpengaruh signifikan terhadap pertumbuhan ekonomi disebabjab karakteristik DAK yang peruntukannya cukup spesifik.

Belum optimalnya dampak yang diberikan dari DAK terhadap pertumbuhan ekonomi dapat disebabkan kurang tepatnya pengalokasian dan kelemahan-kelemahan tata kelola implementasi DAK (Bappenas, 
2011:119). Perencanaan dan pengalokasian DAK kepada daerah-daerah dilakukan secara top-down, dimana daerah tidak terlibat secara langsung dalam perencanaan program atau kegiatan-kegiatan yang akan didanai dengan DAK. Hal tersebut berakibat pada kemungkinan bahwa DAK tidak diarahkan pada program atau kegiatan-kegiatan yang sesuai dengan kebutuhan dan prioritas pembangunan daerah. Pada tahun anggaran 2016 terdapat perubahan kebijakan DAK dimana DAK terbagi menjadi DAK Fisik dan Non Fisik serta perubahan mekanisme pengalokasian DAK dari mekanisme penentuan oleh pemerintah pusat (Top-Down) menjadi mekanisme pengajuan proposal (proposal based) oleh daerah kepada pemerintah pusat.

Menteri Keuangan, Sri Mulyani (dalam news.detik.com tanggal 26 Maret 2018) menyatakan dalam evaluasi DAK fisik dan non fisik ditemukan sejumlah permasalahan pelaksanaan DAK dari 2015, 2016, dan 2017 yang disampaikan oleh sejumlah pimpinan daerah. Permasalahan yang ditemui antara lain dari sisi pelaporan, persyaratan pencairan anggaran dan penyerapan yang tidak maksimal. Selanjutnya, dalam Laporan Kunjungan Kerja Badan Akuntabilitas Keuangan Negara ke Provinsi Jawa Tengah oleh Dewan Perwakilan Rakyat disebutkan permasalahan terkait alokasi DAK berdasarkan Laporan Hasil Pemeriksaan (LHP) atas Laporan Keuangan Bendahara Umum Negara (BUN) tahun 2016 nomor 59a/LHP/XV/05/2017 (hal.56-64) terdapat temuan "Penganggaran Dana Alokasi Khusus (DAK) Fisik Bidang Sarana Prasarana Penunjang dan Tambahan DAK belum memadai". Atas termuan tersebut terdapat permasalahan sebagai berikut: terdapat daerah yang memperoleh alokasi DAK melebihi jumlah yang diajukan dalam proposal; terdapat daerah-daerah yang tidak mengusulkan proposal DAK untuk bidang Jalan/Jembatan dan bidang irigasi, namun justru mendapatkan alokasi tambahan DAK fisik; dan terdapat daerahdaerah yang mengusulkan proposal DAK untuk bidang jalan/jembatan, irigasi/air minum, perdagangan pasar, namun tidak mendapatkan alokasi tambahan DAK fisik. Hal tersebut menunjukkan perlu adanya evaluasi penyerapan DAK terkait koordinasi antara kementerian, lembaga, dan daerah.

\section{Pengaruh Belanja Modal terhadap Pertumbuhan Ekonomi Regional (H5)}

Hasil penelitian menunjukkan bahwa variable $\mathrm{DBH}$ secara parsial berpengaruh positif terhadap pertumbuhan ekonomi. Hasil penelitian ini sejalan dengan penelitian yang dilakukan oleh Nopiani et al. (2016) juga menunjukkan hal yang sama, yaitu belanja modal berpengaruh signifikan dan positif terhadap pertumbuhan ekonomi pada Kabupaten Buleleng. Lebih lanjut dalam penelitian Nopiani, hasil yang signifikan dan positif antara belanja modal dan pertumbuhan ekonomi menunjukkan bahwa belanja modal yang digunakan pemerintah daerah dialokasikan pada belanja 
infrastruktur secara produktif dan juga hasil alokasi belanja modal sudah dapat dinikmati dalam kurun waktu yang pendek atau pembangunan infrastruktur telah berjalan dengan baik.

Belanja modal terutama belanja infrastruktur, mampu memberikan multiplier effect sehingga meningkatkan pertumbuhan ekonomi daerah. Pembangunan infrastruktur seperti jalan akan membantu kelancaran bidang transportasi sehingga mempercepat pergerakan roda perekonomian suatu daerah. Pembangunan irigasi dan darainase lahan pertanian akan meningkatkan produktivitas hasil pertanian. Pengaruh belanja modal ini terhadap pertumbuhan ekonomi daerah dampaknya dua periode berikutnya. Oleh karena itu, pemerintah daerah harus jeli memilih jenis infrastruktur yang didanai dari belanja modal, karena dengan efek ekonominya akan terasa dua periode berikutnya bisa mengakibatkan shortfall penerimaan daerah yang tentunya akan mengganggu cash flow daerah. Lebih jauh bisa berdampak pengelolaan keuangan daerah under budgetary stress.

\section{KESIMPULAN, REKOMENDASI, DAN KETERBATASAN PENELITIAN}

\section{Kesimpulan}

PAD berpengaruh positif terhadap pertumbuhan ekonomi. Hasil ini menunjukkan bahwa pemanfaatan PAD yang dilakukan oleh pemerintah daerah telah berjalan dengan baik untuk mendorong pertumbuhan ekonomi. DAU berpengaruh positif terhadap pertumbuhan ekonomi. Hasil ini menunjukkan bahwa pemanfaatan DAU yang dilakukan oleh pemerintah daerah telah berjalan dengan baik untuk mendorong pertumbuhan ekonomi. DBH berpengaruh signifikan dan positif terhadap pertumbuhan ekonomi. Hasil berjalan dengan baik untuk mendorong pertumbuhan ekonomi. Sementara itu, DAK tidak berpengaruh signifikan terhadap pertumbuhan ekonomi. Hasil ini mengindikasikan bahwa pemanfaatan DAK oleh pemerintah daerah kabupaten/kota belum cukup optimal dalam mendukung upaya peningkatan pertumbuhan ekonomi. Belanja modal berpengaruh signifikan dan positif terhadap pertumbuhan ekonomi. Hasil ini mengindikasikan kebijakan alokasi belanja modal yang dilakukan oleh pemerintah daerah kabupaten/kota berjalan cukup efektif dalam upaya meningkatkan pertumbuhan ekonomi namun efeknya baru terasa dua periode berikutnya.

\section{Rekomendasi}

Pemerintah daerah tetap berupaya meningkatkan kemandirian fiskal dengan berusaha meningkatkan penerimaan PAD melalui intensifikasi dan ekstensifikasi sumber-sumber penerimaan daerah dengan memahami potensi wilayah masing-masing. Pemerintah daerah perlu melakukan kajian lebih lanjut dalam mempertimbangkan alokasi DAU untuk belanja pegawai, 
belanja infrastruktur, dan belanja daerah lainnya sehingga mendorong pertumbuhan ekonomi yang optimal. Pemerintah dapat mengoptimalkan pemanfaatan $\mathrm{DBH}$ sesuai dengan kebijakan pemerintah pusat dengan mengalokasikan minimal $25 \%$ dari $\mathrm{DBH}$ untuk belanja infrastruktur dan untuk membiayai prioritas kebutuhan daerah lainnya yang mendorong pertumbuhan ekonomi. Pemanfaatan DAK yang berbasis output perlu ditekankan dengan serangkaian indikator kinerja yang relevan dengan standar pelayanan minimal masing-masing bidang DAK. Penelitian lebih lanjut diperlukan untuk mengetahui pengaruh masing-masing bidang DAK terhadap pertumbuhan ekonomi. Pemerintah daerah tetap perlu berupaya meningkatkan kualitas belanja modal dengan mengalokasikan sebagian besar belanja modal untuk belanja infrastruktur dan melakukan pengawasan terhadap belanja infrastruktur yang dilakukan agar berjalan dengan baik dan efisien. Penelitian lebih lanjut diperlukan untuk mengetahui pengaruh masing-masing jenis belanja modal terhadap pertumbuhan ekonomi.

\section{Keterbatasan}

Penelitian ini menggunakan lima variabel independen dan satu variabel dependen untuk mencari pengaruh PAD, DAU, DBH, DAK dan belanja modal terhadap pertumbuhan ekonomi. Untuk penelitian selanjutnya diharapkan dapat menggunakan variabel independen atau variabel kontrtol lainnya. Variabel DAK yang digunakan dalam penelitian ini merupakan total DAK secara keseluruhan, sehingga penelitian lebih lanjut diperlukan untuk mengetahui pengaruh masing-masing bidang DAK terhadap pertumbuhan ekonomi. Variabel Belanja modal yang digunakan dalam penelitian ini merupakan nilai dari seluruh jenis belanja modal daerah, sehingga penelitian lebih lanjut diperlukan untuk mengetahui pengaruh masing-masing jenis belanja modal terhadap pertumbuhan ekonomi.

\section{REFERENSI}

Akai. N. dan Sakata, M. 2002. Fiscal Decentralization Contributes to Economic Growth. Evidence from State-Level Cross-Section Data for the United States. Journal of Urban Economics. LII:93-108.

Bahl, Roy. 1999. Implementation Rules for Fiscal Decentralization. Georgia: Georgia State University.

Darma, N.A. 2014. Federal Capital Expenditure and Its Impact on Economic Growth in Nigeria; 1980-2010. Journal of Developing Country Studies. Vol.4: 24-33. Nigeria: University of Abuja.

Dewi, N. W. R. D dan I Dewa G. D. S. 2017. Pengaruh PAD, DAU, DAK, dan Belanja Modal terhadap Pertumbukan Ekonomi. Bali: E-Jurnal Akuntansi Universitas Udayana. 
Harianto, D., dan Priyo H. A. 2007. Hubungan Antara Dana Alokasi Umum, Belanja Modal, Pendapatan Asli Daerah dan Pendapatan Perkapita. Salatiga: Universitas Kristen Satya Wacana.

Hariyanto, Dedy. 2012. Dampak Desentralisasi Fiskal terhadap Pertumbuhan Ekonomi Daerah di Provinsi Jambi. Skripsi: Universitas Indonesia.

Hendriwiyanto, Guntur. 2014. Pengaruh Pendapatan Daerah terhadap Pertumbuhan Ekonomi dengan Belanja Modal sebagai Variabel Mediasi. Skripsi: Universitas Brawijaya

Martinez-Vazquez dan McNab. 2001. Fiscal Decentralization: Issues in Theory and Challenges in Practice. Georgia: Georgia State University.

Mawarni, et al. 2013. Pengaruh Pendapatan Asli Daerah dan Dana Alokasi Umum terhadap Belanja Modal serta Dampaknya terhadap Pertumbuhan Ekonomi Daerah (Studi Pada Kabupaten dan Kota di Aceh). Aceh: Jurnal Akuntansi Pascasarjana Universitas Syiah Kuala.

Nopiani, N. M., Wayan C., dan Fridayana Y. 2016. Pengaruh Pendapatan Asli Daerah, Dana Alokasi Umum, dan Belanja Modal terhadap Pertumbuhan Ekonomi. Singaraja: Universitas Pendidikan Ganesha.

Nugraha, Deni A. 2017. Analisis Pengaruh Pendapatan Asli Daerah, Dana Alokasi Umum, Dana Bagi Hasil, Dana Alokasi Khusus, dan Belanja Modal terhadap Kemiskinan dan PDRB pada Provinsi Jawa Timur. Skripsi: Politeknik Keuangan Negara STAN.

Nugraha, S.H. 2017. Analisis Pengaruh Belanja Pemerintah Provinsi terhadap Pertumbuhan Ekonomi Regional di Indonesia. Skripsi: Politeknik Keuangan Negara STAN.

Nurmainah, S. Analisis Pengaruh Belanja Modal Pemerintah Daerah, Tenaga Kerja Terserap dan Indeks Pembangunan Manusia Terhadap Pertumbuhan Ekonomi dan Kemiskinan. Semarang: Universitas Diponegoro.

Oates, W. E. 1999. An Essay on Fiscal Federalism. Journal of Economic Literature Vol. XXXVII pp. 1120-1149. US: American Economic Association.

Panggabean, Daud Wido Immanuel. 2017. Analisis Pengaruh Pendapatan Asli Daerah dan Dana Perimbangan terhadap Pertumbuhan Ekonomi Kabupaten/Kota di Provinsi Lampung Tahun 2011-2015. Skripsi: Universitas Lampung.

Permanasari, Windhi Amiga. 2013. Pengaruh DAU, DAK, PAD, dan Belanja Modal terhadap Pertumbuhan Ekonomi (Studi Kasus Pada Kabupaten/Kota di Provinsi Jawa Tengah Tahun 2009-2011). Skripsi: Universitas Muhammadiyah Surakarta.

Rahardja, Pratama dan Mandala Manurung. 2015. Pengantar IImu Ekonomi. Jakarta: Lembaga Penerbit Fakultas Ekonomi Universitas Indonesia.

Rahman, Fathur. 2012. Desentralisasi Fiskal dan Minimnya Pembangunan di Indonesia. Jurnal AKP: Vol.1 No.2. 
Romadhon, Wahyu, A. 2017. Pengaruh Pendapatan Asli Daerah dan Dana Alokasi Khusus terhadap Belanja Modal serta Dampaknya terhadap Pertumbuhan Ekonomi. Skripsi: Politeknik Keuangan Negara STAN.

Saragih, Juli P. 2003. Desentralisasi Fiskal dan Keuangan Daerah dalam Otonomi. Jakarta: Ghalia Indonesia.

Setyawati, Anis, dan Ardi Hamzah. 2007. Analisis Pengaruh PAD, DAU, DAK, dan Belanja Pembangunan terhadap Pertumbuhan Ekonomi, Kemiskinan, dan Pengangguran. Jurnal Akuntansi dan Keuangan Indonesia: Vol 4. No.2.

Zhang, T. dan Heng-fu Zou. 1998. Fiscal Decentralization, Public Spending, and Economic Growth in China. Journal of Public Economics. 